\title{
Resources for wounded warriors with major traumatic limb loss
}

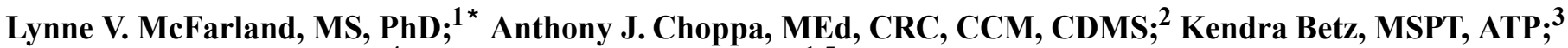 \\ Jonathan D. Pruden, MPS; ${ }^{4}$ Gayle E. Reiber, MPH, PhD ${ }^{1,5}$ \\ ${ }^{1}$ Health Services Research and Development, Department of Veterans Affairs (VA) Puget Sound Health Care System, \\ Seattle, WA; ${ }^{2}$ OSC Vocational Systems, Inc, Bothell, WA; ${ }^{3}$ VA Prosthetics and Sensory Aids Service, Washington, DC; \\ ${ }^{4}$ Wounded Warrior Project, Gainesville VA Medical Center, Gainesville, FL; ${ }^{5}$ Departments of Epidemiology and \\ Health Services, University of Washington, Seattle, WA
}

\begin{abstract}
Many resources are available for servicemembers who experience combat-associated major limb loss. Navigating print, Internet, and in-person information and services is key. This appendix identifies sources of information for individuals with major limb loss as follows: (1) resources for military personnel, (2) resources from the Department of Veterans Affairs, (3) other resources for veterans, (4) resources for family members, and (5) resources in the public domain. Five detailed tables identify some of the agencies, their contact information, and some of the services available in each of these five categories.
\end{abstract}

Key words: amputation, benefits, combat, limb loss, OIF/OEF, prosthetic resources, traumatic amputation, veterans, Vietnam, wounded servicemembers.

\section{INTRODUCTION}

Servicemembers and veterans who experience major limb loss are provided assistance in recovery and rehabilitation but are often frustrated when it comes to finding resources to help them along the way. More than 850 servicemembers and veterans from Operation Iraqi Freedom/ Operation Enduring Freedom (OIF/OEF) [1] and more than 2,500 from the Vietnam war [2] have major limb loss. Many organizations are available to provide assistance and resources to these men and women. The needs of the servicemembers and veterans vary by level of limb loss, severity of other injuries and comorbidities, stage of rehabilitation, need for financial support, benefits, and many other factors. Fortunately, many agencies established services for servicemembers and veterans with major limb loss.

This article identifies information sources for individuals with major limb loss as follows: (1) resources for military personnel, (2) resources from the Department of Veterans Affairs (VA), (3) other resources for veterans, (4) resources for family members, and (5) resources in the public domain. Five detailed tables identify the agencies, their contact information, and services available for each category. These resources were considered helpful by the participants of the Survey for Prosthetic Use (Appendix 1, 
available online only) and the Expert Panel members (Appendix 2, available online only); are known by us to support servicemembers, veterans, and others with limb loss; and are in the public domain. This list is not allinclusive; resources and organizations change rapidly.

\section{RESOURCES FOR MILITARY PERSONNEL}

Numerous support systems are in place for servicemembers with traumatic limb loss while on Active Duty_notably, Walter Reed Army Medical Center, Washington, DC; Brooke Army Medical Center, San Antonio, Texas; and Naval Medical Center, San Diego, California. Military and civilian organizations and agencies provide a broad spectrum of services. Several programs are described next. Table 1 provides additional resources for military personnel.

\section{Army Career and Alumni Program}

The U.S. Army created the Army Career and Alumni Program (ACAP) (http://www.acap.army.mil/) to provide transition assistance to soldiers and family members separating or retiring from Active Duty with ACAP Centers located on most major U.S. Army installations. The program is mandated by Congress and part of U.S. Army/ Department of Defense (DOD) policy. ACAP provides preseparation counseling, employment workshops, VA briefings, employment assistance, tools for writing resumes and cover letters, advice, and support.

ACAP's Disabled Transition Assistance Program (DTAP) is offered for servicemembers who are leaving military service because of disability. This program encourages and assists servicemembers with their decisions about the VA's Vocational Rehabilitation and Employment Service. DTAP facilitates applications for vocational rehabilitation benefits and services. Group sessions explain eligibility, benefits, and availability of educational and vocational counseling. DTAP sessions for hospitalized or convalescing servicemembers are coordinated by the VA Regional Office.

\section{Hope For The Warriors}

Established in 2006, Hope For The Warriors ${ }^{\mathrm{TM}}$ (http:// www.hopeforthewarriors.org) is a civilian, 501(c)(3) nonprofit organization whose mission is to enhance quality of life for wounded U.S. servicemembers and their families with short- and long-term care and to ensure that fallen warriors are not forgotten, nor their families left in need. Its programs include the award-winning "Warrior's Wish," recreational outings, athletic events, transitional housing, financial support for immediate needs, support groups, professional development, and a rehabilitation center.

\section{Military OneSource}

Military OneSource (http://www.militaryonesource.com) has services and information for military personnel and their families who need help with child care, personal finances, emotional support, relocation information, education, elder care, legal advice, and other special circumstances. Face-to-face, telephone, and online counseling by master's-level consultants offer confidential support and practical solutions, 24 hours/day, 7 days/week. Online resources include a library; financial calculators; self-assessment tools; Webinars (interactive online seminars); monthly newsletters; discussion boards; and podcasts on life issues, including stress management, meal planning, depression, families, and relationships. Military OneSource is a civilian organization under contract with the DOD and has no cost for Active Duty, Guard, or Reserve servicemembers and their families.

\section{U.S. Army Wounded Warrior Program}

The U.S. Army Wounded Warrior Program (AW2) (https://www.aw2.army.mil) assists and advocates for wounded soldiers and their families throughout their lifetimes, unconstrained by location or rehabilitation timelines. AW2 embodies the warrior ethos "We will never leave a fallen comrade.” Initially established in April 2004 as the Disabled Soldier Support System for the most severely wounded, injured, or ill soldiers returning from OIF/OEF, AW2 now serves more than 2,300 soldiers and their families. Focusing on those most severely injured, AW2 provides services such as helping wounded soldiers remain in the U.S. Army through education and application assistance, career planning beyond the U.S. Army, education choices, nonmedical benefits, VA and Army benefits, family healthcare, financial counseling for buying a home, local resources, life coaches, and receipt of awards earned during military service. AW2 advocates are located throughout the country at major military treatment facilities and VA medical centers. AW2 assistance requires meeting eligibility requirements (described on its Web site). Its online resources for wounded servicemembers with limb loss include financial assistance, employment opportunities, home improvement assistance, access to assistive technologies including computers, assistance to 
Table 1.

Resources for military personnel.

\begin{tabular}{cll}
\hline Resource & \multicolumn{1}{c}{ Contact Information } & \multicolumn{1}{c}{ Description } \\
\hline America Supports You & http://www.ourmilitary.mil & DOD program launched in 2004 that provides opportu- \\
& nities for citizens to show their support for the U.S. & Armed Forces and to communicate that support to \\
members of the Armed Forces at home and abroad.
\end{tabular}

Army Career and Alumni http://www.acap.army.mil Program

Hope For The Warriors ${ }^{\mathrm{TM}}$ http://www.hopeforthewarriors.org

Injured Marine Semper Fi http://www.semperfifund.org Fund

Military in-Step

http://www.amputee-coalition.org/ military-instep/index.html

Military OneSource

http://www.militaryonesource.com 1-800-342-9647

My Army Benefits
Provides transition assistance to soldiers and family members separating or retiring from Active Duty with advice, support, preseparation counseling, employment assistance, VA briefings, tools for writing resumes and cover letters, and Disabled Transition Assistance Program.

Nonprofit civilian organization established in 2006 to build hope beyond recovery with numerous programs such as award-winning "Warrior's Wish,” recreational outings, athletic events, transitional housing, financial support for immediate needs, support groups, and rehabilitation center.

Nonprofit 501(c)(3) organization established May 2004 that has provided over 10,000 grants totaling $>\$ 24$ million to assist wounded OIF/OEF heroes and families. Financial support is provided for family travel to bedside of wounded Marines; mortgage payments; other immediate financial needs; and perpetuating needs such as modified transportation, home modifications, and specialized equipment.

Guide in partnership with Army Patient Care program and Amputee Coalition of America for adapting to limb loss with $>40$ articles to help with rehabilitation, common problems, military benefits, and sports and recreation resources (organized by sport type).

Online library and resource center provided by DOD at no cost to military members and their families on education, benefits, housing, legal advice, moving information, caregivers, finances, health, career, parenting, and more. Consultants, counseling, and discussion groups are also available.

Official U.S. Army benefits Web site serving regular Army, Army National Guard, Army Reserve, family members, and retirees. "My Benefits" section produces personalized survivor and retirement benefit reports for Active Duty soldiers and family members with complete financial forecast of investments, insurance, and servicemember group life insurance. Also provides "what if" capability that projects how life events, such as getting married, having children, or retiring at a projected date, can affect finances. 
Table 1. (cont)

Resources for military personnel.

TurboTAP (Transition http:/www.transitionassistanceprogram.com Provides information for servicemembers transitioning

Assistance Program) from military. DOD Web site also supported by Department of Labor and VA. Supplements services of Transition Assistance Offices located on major military installations. Topics include career changes, entrepreneurship, healthcare, education, personal finances, relocation, life insurance, loans, and VA benefits.

\author{
U.S. Army Wounded \\ Warrior Program
U.S. Military Services
National Guard
U.S. Air Force
U.S. Army
U.S. Coast Guard
U.S. Marine Corps
U.S. Navy

Yellow Ribbon Fund

\begin{abstract}
https://www.aw2.army.mil
\end{abstract}
http://www.ngb.army.mil

http://www.af.mil

http://www.army.mil

http://www.uscg.mil

http://www.usmc.mil

http://www.navy.mil

http://www.yellowribbonfund.com
U.S. Army program focusing on most severely injured servicemembers with wide range of resources, personal assistance in recovery, and help obtaining benefits.

Official Web sites of U.S. military services.
Private, nonprofit organization providing volunteer services, transportation, and lodging to injured servicemembers and their families. Created in 2005 for injured military recuperating at Walter Reed Army Medical Center and National Naval Medical Center. military family members, outdoor recreational activities, and mobility devices such as Segways ${ }^{\mathrm{TM}}$.

\section{RESOURCES FROM THE DEPARTMENT OF VETERANS AFFAIRS}

Of the 25 million veterans currently alive, nearly 3 of every 4 served during a war or an official period of hostility [3]. About a quarter of the nation's population (approximately 70 million people) is potentially eligible for VA benefits and services because they are veterans, family members, or survivors of veterans [3]. The goal of the VA is to provide excellence in patient care, veteran's benefits, and customer satisfaction. The VA provides an abundance of resources, a few of which are described next, with more listed in Table 2.

The VA's Web site (http://www.va.gov) is the starting point for links to VA benefits, VA healthcare, facility locations, employment, education, home loans, the Home Improvements and Structural Alterations program, automobile modifications, and more. The online version of
"Federal Benefits for Veterans and Dependents" is a comprehensive guide to VA benefits, with contact numbers and Web sites (http://www1.va.gov/opa/vadocs/ fedben.pdf). Veterans may also call 1-800-827-1000. Veterans Service Representatives are available to work oneon-one with veterans and their families. The VA Crisis Intervention Hotline (1-888-899-9377) assists veterans who may be dealing with a mental health crisis or difficult issue in their lives. The hotline also aids family or friends who are assisting a veteran in crisis.

\section{Veterans Health Administration-Veterans Health Care System}

The Veterans Health Administration provides healthcare to veterans transitioning into the Veterans Health Care System (http://www1.va.gov/health/index.asp). A wide range of healthcare services are provided and many Web sites offer information. Eligibility, enrollment, and coverage changes for VA healthcare are described (http:// www.va.gov/healtheligibility). Servicemembers from OIF/ OEF can use the portal for "Returning Service Members" 
Table 2 .

Resources from Department of Veterans Affairs (VA).

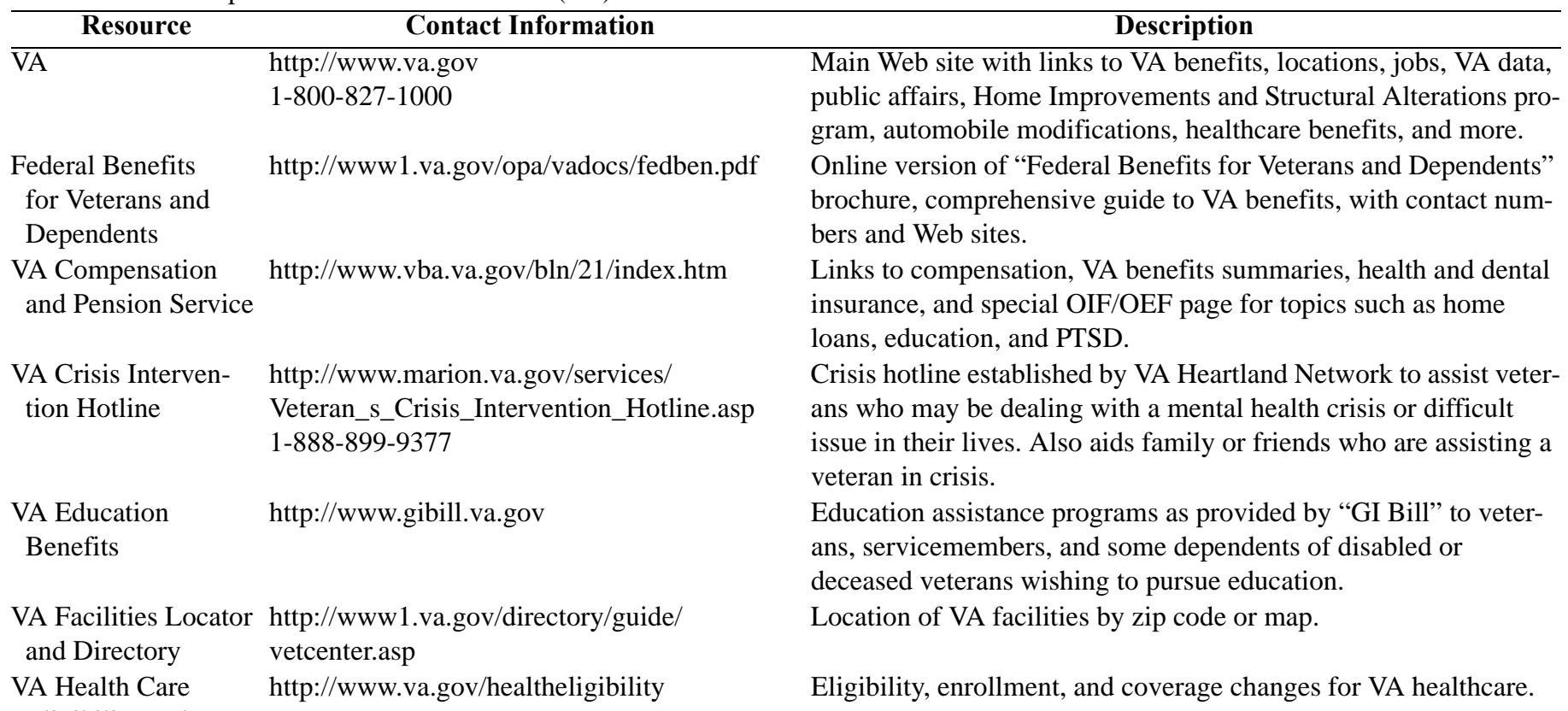

Eligibility and

Enrollment

VA Health Care-

Veterans Health

http://www1.va.gov/health

Overview of VA healthcare programs.

Administration

VA Home Loan

Guaranty Services

VA Life Insurance

Programs

VA My HealtheVet

VA National Center

for Posttraumatic

Stress Disorder

VA National

Programs and

Special Events

VA Polytrauma

System of Care

VA Prosthetics and Sensory Aids

Service

VA Returning

Service Members

(OEF/OIF)

VA Veterans Service http://www1.va.gov/VSO

Organizations

VA Vocational

Rehabilitation and

http://www.homeloans.va.gov

http://www.insurance.va.gov

http://www.myhealth.va.gov

http://www.ncptsd.va.gov/ncmain

http://www1.va.gov/opa/speceven/natpro/

Default.asp

http://www.polytrauma.va.gov

http://www.prosthetics.va.gov

Current updates on home loans for veterans.

Life insurance programs for servicemembers and veterans.

Portal to individual VA healthcare and concerns.

Information on PTSD such as coping with war, resources for families, effects of serving in OIF/OEF, diagnosis and treatment, and "PTSD Information Center" link.

National annual events for veterans, including Winter Sports Clinic, Wheelchair Games, Summer Sports Clinic, Golden Age

Games, and National Veterans Creative Arts Festival.

Care for veterans with multiple injuries and locations of polytrauma facilities.

Information on prosthetic devices and all other adaptive equipment and technologies provided to VA healthcare beneficiaries.

Answers to questions and timely information for OIF/OEF servicemembers.

Online database of chartered and unchartered veterans service organizations.

Vocational rehabilitation services for veterans with serviceconnected disabilities, including independent living, educational/ vocational counseling, small business information, translating military skills into occupational skills, and employment opportunities through http://vetsuccess.gov. 
(tap://www.oefoif.va.gov/). My HealtheVet (accessed from http://www.myhealth.va.gov) is the portal for individual healthcare and concerns.

\section{VA Vocational Rehabilitation and Employment Program}

VA Vocational Rehabilitation and Employment (http:// www.vba.va.gov/bln/vre/) provides vocational rehabilitation services for veterans with service-connected disabilities, including independent living and educational/ vocational counseling, small business information, translating military skills into occupational skills, and employment opportunities through http://vetsuccess.gov.

\section{VA Prosthetics and Sensory Aids Service}

The VA Prosthetics and Sensory Aids Service (http:// www.prosthetics.va.gov) provides adaptive equipment, assistive technologies, artificial limbs, home and vehicle adaptations, wheeled mobility devices, and adaptive sports equipment to VA healthcare beneficiaries. The Web site provides information about the availability of adaptive equipment and technologies, upcoming events, important announcements, and links to new technologies, new prosthetic devices, the VA Benefits Handbook, and the "Veterans for America Survival Guide."

\section{VA Polytrauma System of Care}

Polytrauma is defined as two or more injuries to physical regions or organ systems, one of which may be life threatening, that result in physical, cognitive, psychological, or psychosocial impairments and functional disability (such as traumatic brain injury, hearing loss, major limb loss, factures, burns, and visual impairment). Care for returning servicemembers and veterans with these injuries is provided at 4 polytrauma centers and 17 additional network sites by teams of healthcare professionals who develop individual rehabilitation plans to maximize recovery. The Web site (http://www.polytrauma.va.gov) has information on admission criteria, family support, polytrauma care news, "Frequently Asked Questions," and a locator for VA Polytrauma Rehabilitation Centers and Polytrauma Network Sites.

\section{OTHER RESOURCES FOR VETERANS}

Many organizations outside of the VA provide support to veterans. Several are described here, and more are listed in Table 3.

\section{American Veterans}

American Veterans (AMVETS) (http://www.amvets.org) is a volunteer-led organization open to anyone who is currently serving or who has honorably served in the U.S. Armed Forces from World War II to the present. For more than 60 years, AMVETS has assisted veterans and sponsored numerous programs that serve the country and its citizens. Their national network of trained national service officers, accredited by the VA, provides advice and prompt action on compensation claims at no charge to the veteran. Additionally, this organization offers professional advice on veterans' benefits and is involved with legislative efforts in Washington, DC. Its Web site features news for veterans, lists of resources, and a career center.

\section{Vietnam Veterans of America}

Since 1978, Vietnam Veterans of America (http:// www.vva.org) has been dedicated to Vietnam-era veterans and their families through advocacy for all issues important to Vietnam war veterans, creation of a positive public perception, community service, pursuit of an accounting for POW/MIAs (prisoners of war/missing in action), and support for the next generation of warriors. A Congressionally chartered, not-for-profit corporation, it was founded on the principle "Never again will one generation of veterans abandon another." Their hotline (1-800-273-8255) is available 24 hours/day, 7 days/week.

\section{Veterans for America}

Veterans for America (http://www.veteransforamerica. org), a nonprofit organization also known as Vietnam Veterans of America Foundation, is an advocacy and humanitarian organization seeking to ensure that the needs of servicemembers and veterans from OIF/OEF are met, focusing on traumatic brain injuries and psychological traumas. Resources include the free 599-page "Survival Guide,” a step-by-step road map for navigating the bureaucracies and services that aid veterans, as well as advice and strategies for dealing with difficult issues such as harassment and caregiving. Its Wounded Warrior Outreach Program sponsors one-on-one visits by OIF/OEF servicemember liaisons to troops suffering from psychological and neurological combat injuries to bring trends to military leaders.

\section{Disabled American Veterans}

Disabled American Veterans (DAV) (http://www.dav. org) is dedicated to creating better lives for disabled U.S. 
Table 3.

Other resources for veterans.

\begin{tabular}{ll}
\hline \multicolumn{1}{c}{ Resource } & \multicolumn{1}{c}{ Contact Information } \\
\hline American Veterans & http://www.amvets.org \\
& \\
& \\
& \\
& \\
American Veterans & http://www.avbi.org \\
with Brain Injuries & \\
& \\
Disabled American & http://www.dav.org \\
Veterans & 877-I AM A VET [877-426-2838]
\end{tabular}

Military Order of the Purple Heart

National Veterans

Foundation

Paralyzed Veterans

of America

http://www.pva.org

1-800-424-8200

Segs4Vets

U.S. VETS

Vets Coming Home

http://www.vetscominghome.com

Veterans for America

http://www.veteransforamerica.org

Veterans and Families http://www.veteransandfamilies.org Foundation

http://www.purpleheart.org

703-642-5360

http://www.nvf.org

1-888-777-4443

http://www.segs4vets.org

http://www.usvetsinc.org
Clearinghouse with links to books, counseling resources, Federal and state agencies, PTSD groups, and other veterans groups

Nonprofit organization, also known as Vietnam Veterans of America Foundation, to ensure that needs of servicemembers and veterans from OIF/OEF are met, focusing on traumatic brain injuries and psychological traumas. Resources include 599-page "Survival Guide” to help navigate bureaucracy.

501(c)(3) nonprofit community service and support organization to aid veterans and their families in homecoming transition by helping veterans decompress from war and deployment, both mentally and emotionally, and transition back into family and civilian life. 
Table 3. (cont)

Other resources for veterans.

Veterans of Modern http://www.vmwusa.org Warfare

New nonprofit membership organization dedicated to meeting needs of most recent war veterans who served from 1990 to present, through benefits access, seamless transitions, healthcare, and advocacy. Emphasis is on timely communication and camaraderie.

Vietnam Veterans of http://www.vva.org America 1-800-273-8255
Congressionally chartered, not-for-profit corporation since 1978 dedicated to Vietnam-era veterans and their families through advocacy for all issues important to Vietnam veterans, creation of positive public perception, serving the community, and support for next generation of warriors.

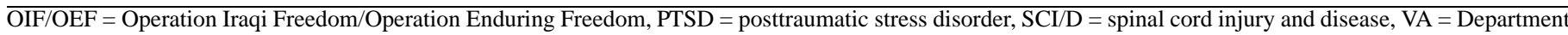
of Veterans Affairs.

veterans and their families through a variety of free services. The DAV's National Service Officers assist and represent veterans in filing claims with the VA-free of charge-for disability compensation and pension, vocational rehabilitation, home loan guaranty, and any other benefit program.

The DAV also educates veterans and their families on benefits and services, helps homeless veterans transition to a productive lifestyle, organizes volunteers to drive veterans to and from VA medical facilities, offers disaster relief, publishes DAV Magazine, hosts events such as the Winter Sports Clinic, and advocates for legislation for veterans and their benefits.

\section{Paralyzed Veterans of America}

Paralyzed Veterans of America (http://www.pva.org), a Congressionally chartered veterans service organization founded in 1946, seeks to maximize the quality of life for veterans with spinal cord injury and disease (SCI/D). It advocates for and provides information on SCI/D health issues, SCI/D research and education, veterans benefits and issues, accessiblity design in architecture and construction, legal issues, sports, and recreation.

\section{RESOURCES FOR FAMILY MEMBERS}

Families often require assistance immediately after a member of their family is wounded and may not know where to turn. Participants in the Survey for Prosthetic Use found the following organizations useful for family support. Table 4 provides a detailed list for families, including transportation assistance programs.

\section{Iraq War Veterans Organization, Inc}

The Iraq War Veterans Organization, Inc, (http:// www.iraqwarveterans.org) supports veterans and family members from OIF/OEF and the Global War on Terror. Information is provided for Active Duty military and their families on predeployment, deployment, and postdeployment issues. The Web site has links to information on VA healthcare; VA benefits; readjustment after deployment; education; employment opportunities; military discounts; posttraumatuc stress disorder issues; support chat forums; family support; and other communitybuilding resources, including a "Military Matchmaker.”

\section{National Military Family Association}

The National Military Family Association (NMFA) (http://www.militaryfamily.org) was organized in 1969 as the National Military Wives Association by a group of wives and widows seeking financial security for survivors of uniformed service personnel and retirees. Their efforts resulted in the Survivor Benefit Plan. Since then, NMFA has been at the forefront of advocacy for improvements in the quality of military family life. NMFA is a nonprofit 501(c)(3) association with support from the seven uniformed services and works regularly on common concerns with The Military Coalition, an umbrella organization of 36 military-related associations. NMFA educates the public, the military community, and Congress on the rights and benefits of military families and advocates with Congress and DOD agencies for an equitable quality of life for those families. NMFA's accomplishments, in conjunction with The Military Coalition, include improvements to medical and dental benefits, education for dependents, services for military children with autism, military housing allowances, relocation coverage, spousal 
Table 4.

Resources for family members.

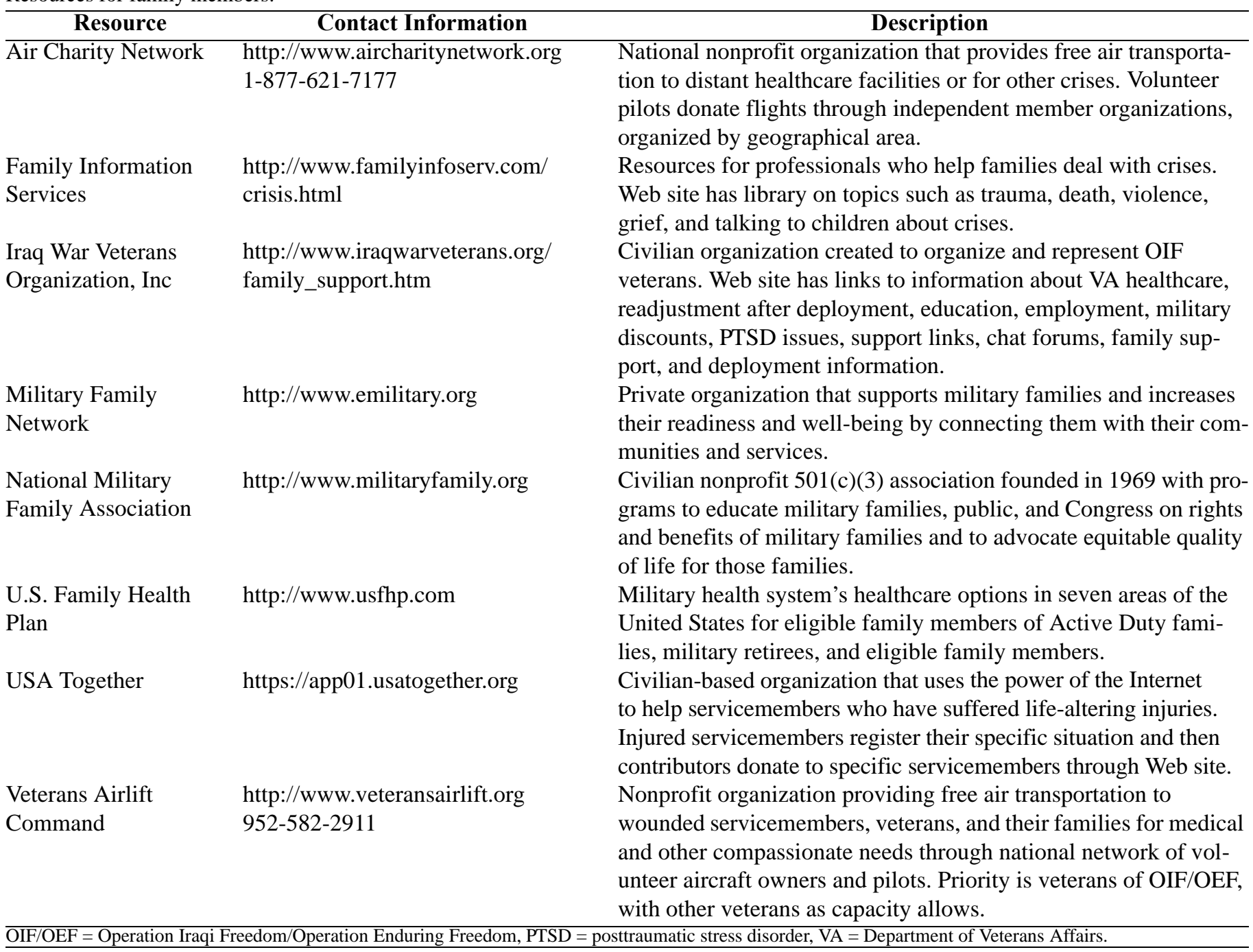

employment opportunities, and retiree and survivor benefits.

\section{RESOURCES IN PUBLIC DOMAIN}

Many public organizations are dedicated to helping wounded servicemembers, veterans, their families, and others with limb loss. Details on a few are described below, with more listed in Table 5.

\section{Amputee Coalition of America}

The Amputee Coalition of America (ACA) (http:// www.amputee-coalition.org) is a national nonprofit con- sumer educational organization representing people who have experienced amputation or were born with limb differences. The ACA network includes people with limb loss, their friends and family, support groups, professionals, limb loss-related agencies, and educational organizations. The ACA was incorporated in 1989 and is governed by a Board of Directors, the majority of whom are people with limb loss.

The ACA believes that education enables those with limb loss to play a central role in decisions about their care, services, and outcomes, a role that is crucial to achieving their highest potential and self-fulfillment. To empower the individual with limb loss, the ACA provides educational resources that include inMotion magazine, booklets, fact sheets, videotapes, and Military in-Step (in 
JRRD, Volume 47, Number 4, 2010

Table 5.

Resources in public domain for people with limb loss.

\begin{tabular}{ccl}
\hline Resource & \multicolumn{1}{c}{ Contact Information } & Description \\
\hline Above Knee Amputee & http://abovekneeamputee.com & $\begin{array}{l}\text { Maintained by people with above-knee limb loss and their friends to } \\
\text { help them achieve success with their prosthesis and related issues. } \\
\end{array}$ \\
& $\begin{array}{l}\text { Support includes dealing with emotional issues, message boards, } \\
\text { links, and tips. Membership provides access to prosthetist rating } \\
\text { page. }\end{array}$ \\
Active Living Magazine http://www.activelivingmagazine.com & Features articles on adapted activities, travel resources, and tools for
\end{tabular}
maintaining active life with amputation or other disability. Requires subscription.

$\begin{array}{ll}\text { Adaptive Sports } & \text { http://www.adaptivesportsfounda- } \\ \text { Foundation } & \text { tion.org }\end{array}$

American Academy http://www.oandp.org

of Orthotists and Pros-

thetists

American Amputee

Foundation

American Orthotic \&

Prosthetic Association

Amputee Coalition of America

http://www.aopanet.org

http://www.amputee-coalition.org 1-800-267-5669

Amputee Coalition of America-en español The Amputee Network

http://www.amputee-coalition.org/ nllic_spanish.asp

http://homepage.mac.com/birdhousestudios/AmputeeNetwork.htm

Amputee Resource http://www.amputeeresource.org

Foundation of America, Inc

Arm-Amp.Com

http://www.arm-amp.com

Arm Amputee Program, http://nrhrehab.org/Patient+Care/

National Rehabilitation Programs+and+Service+Offerings/

Hospital

Outpatient+Services/

Service_Page.aspx?id=121

202-877-1875

The Care Planner http://www.careplanners.net/index.asp
Nonprofit organization since 1984 that has provided both winter and summer sports instruction to children and adults with cognitive and physical disabilities.

For-profit trade association founded in 1970 assisting orthotic and prosthetic facilities, manufacturers, and suppliers. Membership required, but Journal of Orthotics and Prosthetics is available at this Web site.

Nonprofit educational organization established in 1975 as national information clearinghouse and referral center serving people with limb loss, their families, and care providers. Some information is free; newsletter and additional information available to members only.

For-profit national trade association founded in 1917 with services and products for orthotic and prosthetic professionals. Requires membership.

National nonprofit consumer educational organization representing people who have experienced amputation or were born with limb differences and empowering them through educational resources, legislative advocacy, and National Peer Network. Resources include inMotion magazine, limb loss news, National Limb Loss Information Center, booklets, fact sheets, videotapes, online bulletin board, toll-free hotline, peer training, and links to other Web sites, organizations, and prosthetic manufacturers.

Amputee Coalition of America Web site offered in Spanish.

Web site to educate people with limb loss and their families and friends, with primary objective of helping with prosthetic rehabilitation. Site offers stories of people with limb loss, blog, and featured monthly links.

Nonprofit Web-based information resource funded through public donations with resource links, articles, tips for finding prosthetist, published articles, and link to "Amputees in Hollywood."

Web site run by people with upper-limb amputations, featuring profiles of people with upper-limb amputations, tips, suggestions, chat room, and links.

Private nonprofit program providing prosthetic training for servicemembers with upper-limb amputations in District of Columbia.

Nonprofit organization dedicated to professionals in life planning and case management. 
Table 5. (cont)

Resources in public domain for people with limb loss.

Challenged Athletes http://www.challengedathletes.org

Foundation 858-866-0959

Charleston Amputee

Support Team

Digital Resource

Foundation for the

Orthotics and Prosthet-

ics Community

Disabled Sports USA http://www.dsusa.org

Fashion Magic Apparel http://www.fashionmagic.bc.ca

The Given Limb

Foundation

Helping a Hero

Hemipelvectomy and

Hip-Disarticulation

Amputee Support

National Amputee Golf http://www.nagagolf.org Association

National Institute of Neurological Disorders and Stroke

National Limb Loss

Center

National Peer Network

O\&P Digital

Technologies http://www.givenlimb.org http://www.charlestonamputee supporteam.com

http://www.drfop.org

http://www.helpingahero.org 1-888-786-9531

http://www.hphdhelp.org
Unique nonprofit organization established in 1997 to help people with disabilities pursue active lifestyle through physical fitness and support athletic greatness inherent in all people with physical challenges through grants for training, competition, and equipment needs. Operation Rebound specifically supports servicemembers and veterans.

Civilian support team for amputees in Charleston, South Carolina, area, offering support group meetings, events, and links to other services available. Part of Amputee Coalition of America.

Nonprofit organization with mission to develop computer-based information resources and communication for worldwide orthotics, prosthetics, and rehabilitation community. Online resources are "Humanitarian Database" connecting communities of need with professionals and organizations that can help and "Virtual Library" of orthotics and prosthetics reference materials, available free to users worldwide.

Nonprofit 501(c)(3) organization established in 1967 by disabled Vietnam veterans to serve war injured through community-based chapters offering variety of recreation programs to anyone with permanent disability. Wounded Warrior Disabled Sports Project supports severely wounded servicemembers from OIF/OEF and Global War on Terror.

For-profit company selling custom clothes to fit with wheelchair or with specific needs of people with limb loss.

Nonprofit organization established in 2007 to help improve lives of persons throughout world with limb loss or diminished use of their limbs, from servicemembers to victims of land mines. Supports new initiatives, including tool kit for minor repairs for prosthetic devices. Nonprofit organization providing support for severely injured military personnel. Scholarship support, new homes, recreation, etc.

Private voluntary site for support of people with hip disarticulation and hemipelvectomies through peer support/communication, physical fitness, education, hints, and prosthetic/adaptive-technology information.

Association started by 12 World War II veterans with limb loss incorporated in 1954 and supported by Professional Golf Association and U.S. Golf Association. Sponsors golf programs such as First Swing to teach adaptive golf to people with physical disabilities, brings golf to rehabilitation centers and hospitals for people with limb loss, organizes tournaments, and publishes magazine.

http://www.ninds.nih.gov/disorders/tbi U.S. government (National Institutes of Health) Web site with information and links on traumatic brain injury, including educational booklets, publications, organizations, research, and clinical trials. See “Amputee Coalition of America.”

http://www.amputee-coalition.org/ nllic_about.html

http://www.amputee-coalition.org/ npn_about.html 1-888-267-5669

http://www.oandp.com
See “Amputee Coalition of America.” Peer network to connect people with limb loss with trained peers and support groups.

Web site providing comprehensive information and services for orthotics and prosthetics professionals, focusing on Web/software development and new technologies. 
Table 5. (cont)

Resources in public domain for people with limb loss.

O\&P Online Library http://www.oandplibrary.org

Project Healing Waters http://projecthealingwaters.org Fly Fishing

Team River Runner http://www.teamriverrunner.org

Warriors \& Quiet Water http://warriorsandquietwaters.org Foundation

Wounded Warrior Out- http://www.veteransforamerica.org/ reach Program our-programs/

Wounded Warrior Project

http://www.woundedwarriorproject.org
Virtual library for orthotics and prosthetics community in partnership with O\&P Digital Technologies.

Nonprofit organization which introduces fly fishing to servicemembers and veterans with disabilities to aid in their physical and emotional recovery.

Nonprofit, all-volunteer organization, established in 2004 by kayakers in Washington, DC, area to help Active Duty military and veterans find health, healing, and new challenges through whitewater boating on Potomac River, in partnership with The Wounded Warrior Project and Disabled Sports USA.

Nonprofit corporation providing rehabilitative recreation through fly fishing on Montana's rivers and streams primarily for wounded servicemembers still in military hospital system.

Run by Veterans for America nonprofit organization. Sponsors oneon-one visits by OIF/OEF servicemember liaisons to troops suffering from psychological and neurological combat injuries to bring trends to military leaders.

Nonprofit organization that empowers severely injured servicemembers through peer support, community involvement and awareness, and programs and services such as career planning, family services, rehabilitative cycling program, transition training, and advocacy for positive changes in veterans benefits and policy. cooperation with the U.S. Armed Forces Amputee Patient Care Program). Its National Limb Loss Information Center (partially supported by the Center for Disease Control and Prevention) provides resources on diverse topics including surgery, people with new limb loss, statistics, financial help, prosthetics, infection, and help for children coping with parental limb loss. Links direct people with limb loss to other Web sites, organizations, and prosthetic manufacturers.

The ACA also advocates on behalf of people with limb loss through government legislation, community outreach, and the dissemination of accurate information about the U.S. population of people with limb loss to the government, industries, and general public. The ACA promotes full implementation of the Americans with Disabilities Act and informs policy makers of the issues of people with limb loss.

The ACA promotes peer support through an online bulletin board, a toll-free hotline, guidelines for starting support groups, and a National Peer Network. A database of trained and experienced peers enables connections by telephone, fax, email, postal service, or personal visits. The ACA provides training seminars to develop the objectivity, listening skills, and appropriate techniques that will enhance the possibility of successful communication. Trained peers are usually people with limb loss who have transitioned successfully to their new life. In addition, the ACA works collaboratively with support groups to provide peer training, training manuals, funding sources, and educational materials.

\section{Wounded Warrior Project}

The purpose of the nonprofit organization Wounded Warrior Project (http://www.woundedwarriorproject.org) is to honor and empower wounded warriors by raising public awareness and support for the needs of severely injured servicemembers; help wounded servicemembers aid and assist each other; and provide programs and services such as career planning, family services, a rehabilitative cycling program, transition training, and advocate for positive changes in veterans benefits and policy. Its core values are fun, integrity, loyalty, innovation, and service.

\section{CONCLUSIONS}

This article presents examples of the wide selection of resources available to support servicemembers, veterans, 
and their families who are experiencing the challenges involved in recovering from major limb loss. A large variety of military and veterans benefits and organizations are available that assist in healthcare, transportation, housing and automobile modifications, emotional support, exploration of innovative prosthetic device technologies, recreation, and community building. We hope that this article acts as a portal for servicemembers, veterans, and their families to find the support they may need and to realize the wide diversity of resources that are available to them.

\section{ACKNOWLEDGMENTS}

\section{Author Contributions:}

Study concept and design: L. V. McFarland, A. J. Choppa, K. Betz, J. D. Pruden, G. E. Reiber. Acquisition of data: L. V. McFarland, J. D. Pruden, G. E. Reiber. Drafting of manuscript: L. V. McFarland, A. J. Choppa, K. Betz, J. D. Pruden, G. E. Reiber.

Critical revision of manuscript for important intellectual content: L. V. McFarland, A. J. Choppa, K. Betz, J. D. Pruden, G. E. Reiber. Obtained funding: G. E. Reiber.

Financial Disclosures: The authors have declared that no competing interests exist.

Funding/Support: This material is based on work supported by the VA Health Services Research and Development (grant IIR 05-244) and a Career Scientist Award to Dr. Reiber (grant RCS 98-353).

Additional Contributions: We thank all the participants in the Survey for Prosthetic Use and the Expert Panel members for their valuable assistance. We would like to acknowledge the assistance of Julie Bondzie, Koriann Brousseau, and Jane Emens for assistance in data collection and manuscript preparation.

The resources named in this article are recommended by the participants of the Survey for Prosthetic Use and by members of the Expert Panel. Our focus is government, voluntary, and nonprofit agencies. We recognize that these resources are dynamic and ever changing and that this list is not exhaustive. Inclusion of any organization or Web site in this article does not constitute official endorsement by the VA, DoD, or any of the authors and is for informational purposes only.

The views expressed in this article are those of the authors and do not necessarily reflect the position or policy of the VA or the DoD.

\section{REFERENCES}

1. Scoville C. Amputee patient numbers thru January 2009. Email to: GE Reiber. 2009 Jan 31.

2. Maynard C, Flohr B, Guagliardo TA, Martin CH, McFarland LV, Pruden JD, Reiber GE. Department of Veterans Affairs compensation and medical care benefits accorded to veterans with major limb loss. J Rehabil Res Dev. 2010;47(4): 403-8.

3. About VA [Internet]. Washington (DC): Department of Veterans Affairs [cited 2009 Feb 23]. Available from: http://www.va.gov/about va/.

Submitted for publication February 24, 2009. Accepted February 24, 2009. 